\title{
INJECTION POWER UPFC MODEL FOR INCORPORATION OF UNIFIED POWER FLOW CONTROLLER IN LOAD FLOW STUDIES
}

\author{
M. Z. EL-Sadek, M. Abo-Zahhad, A. Ahmed, H.E. Zidan \\ Electrical Engineering Department, Faculty of Engineering, Assiut \\ University, Assiut, Egypt. $\quad$ E-mail: $\underline{\text { a_ahmed@aun.edu.eg }}$
}

(Received Nov. 27, 2006, Accepted Jan. 20, 2007

\begin{abstract}
This paper is devoted to the incorporation of the steady-state model of the unified power flow controller (UPFC) in power flow programs using a UPFC injection model. The adopted UPFC injection model is based on the representation of UPFC in steady-state conditions by two voltage sources in series with certain reactances. Using this UPFC power flow model, the effects of UPFC control variables on system voltage magnitude, line active and reactive power flow, total system losses, slack bus generated active and reactive power and the injected reactive power from voltage controlled buses are illustrated. Also, the effects of the UPFC location and the UPFC series converter coupling transformer reactance on power flows and on total system real power loss are studied. It is found that using this UPFC power flow model it is possible to show the power flow characteristics inside the UPFC converters, themselves.
\end{abstract}

KEYWORDS: Flexible AC transmission systems (FACTS), Unified power flow controller (UPFC), Load flow analysis, MATLAB.

\section{INTRODUCTION}

During the last decade, continuous and fast improvement of power electronics technology has made flexible AC transmission systems (FACTS) a promising concept for power system applications [1,2]. With the application of FACTS technology, power flow along transmission lines can be more flexibly controlled [3]. Among a variety of FACTS controllers, the unified power flow controller, abbreviated (UPFC) is one of the more interesting and potentially the most versatile. [4]. It can provide simultaneous and independent control of important power system parameters such as line active power flow, line reactive power flow, line impedances, and node voltages [5]. Thereby, it offers the necessary functional flexibility for the combined application of voltage magnitude and phase angle control with combined controlled series and shunt compensation. The UPFC operation mode (terminal voltage regulation, series reactances compensation, phase shift, or any combination of them) can be changed 
from one state to another without hardware alternators to adapt particular changing system conditions. This feature makes it a competent device. Computation and control of power flow for power systems embedded with UPFC appear to be fundamental for power system analysis and planning purposes. A mathematical model is required for investigation the effects of UPFC on power system operation.

In this paper, an injection power UPFC proposed by Noroozian in ref.[6], is incorporated in a MATLAB power flow program [7] based on Newton-Raphson algorithm. This UPFC power flow model is capable of giving investigations of the effects of the UPFC on power system operation. Using this UPFC power flow model, the effect of UPFC location on power flow and overall transmission real power losses is studied and illustrated. The UPFC power flow characteristics inside the UPFC converters are cleared.

\section{Injection Power UPFC Model:}

\subsection{UPFC Construction}

Fig. 1 shows the basic circuit arrangement of the UPFC where it consists of two switching converters. These converters are operated from a common DC link provided by a DC storage capacitor. Converter 2 provides the main function of the UPFC by injecting an AC voltage with controllable magnitude and phase angle in series with the transmission line via a series transformer. The basic function of converter 1 is to supply or absorb the real power demand by converter 2 at the common DC link. It can also generate or absorb controllable reactive power and provide independent shunt reactive compensation for the line. Converter 2 supplies or absorbs locally the required reactive power and exchanges the active power as a result of the series injection voltage.

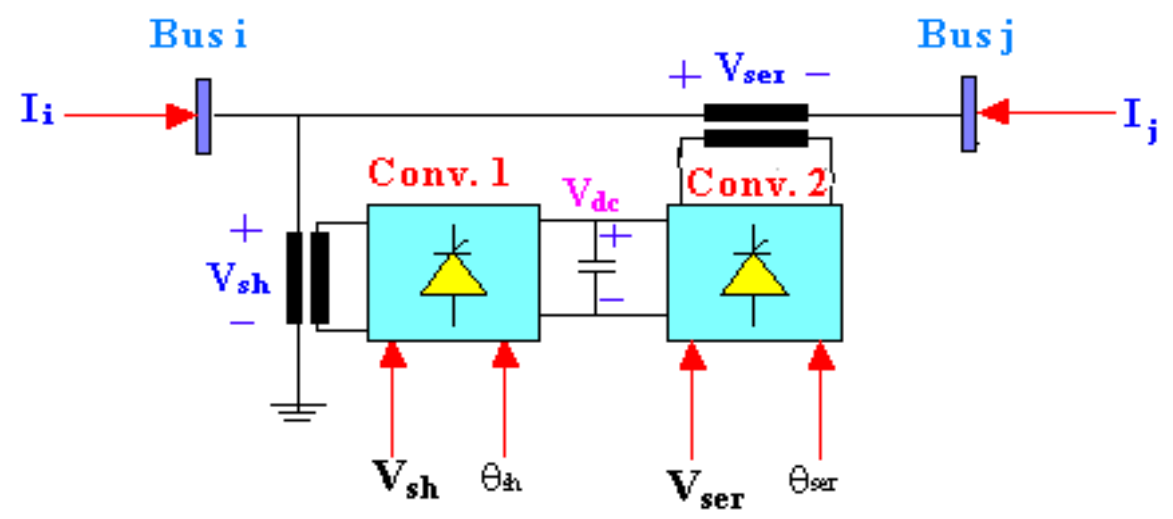

Figure 1: UPFC components.

\subsection{UPFC Steady-State Representation}

A UPFC can be represented in steady-state conditions by two voltage sources representing fundamental components of output voltage waveforms of the two converters and impedances being leakage reactances of the two coupling transformers. 
Fig. (2) depicts a two voltage-source model of UPFC. The voltage sources, $\mathrm{V}_{\text {ser }}$ and $\mathrm{V}_{\text {sh }}$ are controllable in both magnitudes and phase angles. $\mathrm{V}_{\text {ser }}$ should be defined as:

$\mathrm{V}_{\text {ser }}=r \mathrm{~V}_{\mathrm{i}} \mathrm{e}^{\mathrm{j} \theta \text { ser }}$

The values of $\mathrm{r}$ and $\theta_{\text {ser }}$ are defined within specified limits given by the following Eqn. (2).

$0 \leq \mathrm{r} \leq \mathrm{r} \max$ and $0 \leq \theta_{\text {ser }} \leq 2 \pi$

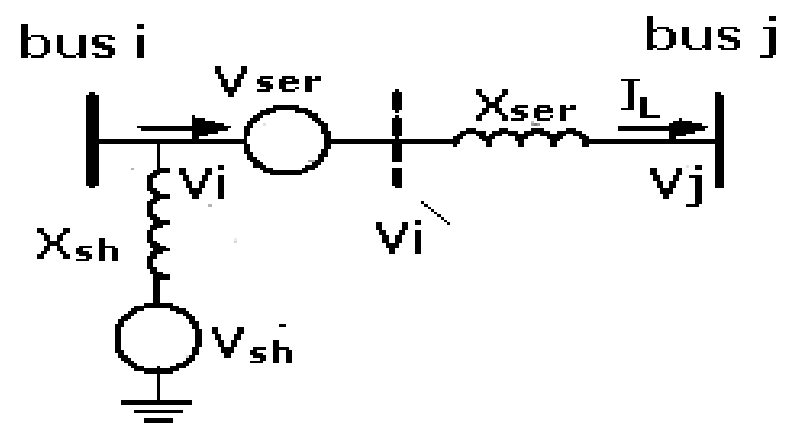

Figure 2: UPFC equivalent circuit.

\subsubsection{Series Connected Voltage Source Converter Model}

The steady-state UPFC mathematical injection model is developed by replacing voltage source $V_{\text {ser }}$ by a current source $I_{\text {ser }}$ parallel with a susceptance $b_{\text {ser }}=$ $1 / \mathrm{X}_{\text {ser }}$. Therefore, the series current $\mathrm{I}_{\text {ser }}$ is defined by:

$\mathrm{I}_{\text {ser }}=-\mathrm{j} \mathrm{b}_{\text {ser }} \mathrm{V}_{\text {ser }}$

The current source $I_{\text {ser }}$ can be replaced by injected power at the two auxiliary buses $i$ and $\mathrm{j}$ between which the UPFC is connected as shown in Fig. (4).

$\mathrm{S}_{\text {is }}=\mathrm{V}_{\mathrm{i}}\left(-\mathrm{I}_{\mathrm{ser}}\right)^{*}$

$\mathrm{S}_{\mathrm{js}}=\mathrm{V}_{\mathrm{j}}\left(\mathrm{I}_{\mathrm{ser}}\right)^{*}$

The injected powers $S_{\text {is }}$ and $S_{\text {js }}$ can be simplified according to the following operations, by substituting Eqns. (1) and (3) into (4), (5). The power injected in bus i is found by substituting Eqns. $(1,3)$ in $(4)$ to yield:

$\mathrm{S}_{\text {is }}=\mathrm{V}_{\mathrm{i}}\left(\mathrm{j} \mathrm{b}_{\text {serr }} \mathrm{r} \mathrm{V}_{\mathrm{i}} \mathrm{e}^{\mathrm{j} \mathrm{ser}_{\mathrm{ser}}}\right)^{*}=-\mathrm{rb}_{\text {ser }} \mathrm{V}_{\mathrm{i}}^{2} \sin \theta_{\text {ser }}-\mathrm{jr} \mathrm{b}_{\text {ser }} \mathrm{V}_{\mathrm{i}}^{2} \cos \theta_{\text {ser }}$

Eqn. (6) can be decomposed into its real and imaginary components, $S_{\text {is }}=P_{\text {is }}+j Q_{\text {is }}$, where

$\mathrm{P}_{\mathrm{is}}=-\mathrm{rb}_{\mathrm{ser}} \mathrm{V}_{\mathrm{i}}^{2} \sin \theta_{\text {ser }}$ 
$\mathrm{Q}_{\mathrm{is}}=-\mathrm{rb}_{\mathrm{ser}} \mathrm{V}_{\mathrm{i}}^{2} \cos \theta_{\text {ser }}$

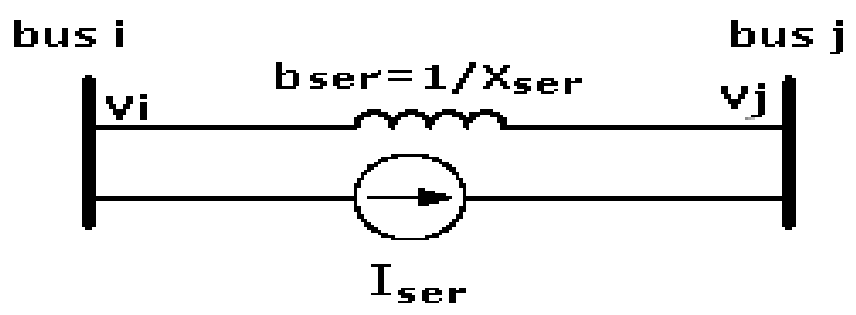

Figure 3: Replacement of series voltage source by a current source.

Similarly the power injected at bus $\mathrm{j}$ is obtained by substituting Eqns. $(1,3)$ into Eqn.

(5) to yield:

$\mathrm{S}_{\mathrm{js}}=\mathrm{V}_{\mathrm{i}} \mathrm{V}_{\mathrm{j}} \mathrm{b}_{\mathrm{ser}} \sin \left(\delta_{\mathrm{ij}}+\theta_{\mathrm{ser}}\right)+\mathrm{j} \mathrm{V}_{\mathrm{i}} \mathrm{V}_{\mathrm{j}} \mathrm{b}_{\mathrm{ser}} \mathrm{cos}\left(\delta_{\mathrm{ij}}+\theta_{\mathrm{ser}}\right)$

Eqn. (9) can also be decomposed into its real and imaginary parts, $S_{j s}=P_{j s}+j Q_{j s}$, with:

$\mathrm{P}_{\mathrm{js}}=\mathrm{V}_{\mathrm{i}} \mathrm{V}_{\mathrm{j}} \mathrm{b}_{\mathrm{ser}} \mathrm{sin}\left(\delta_{\mathrm{ij}}+\theta_{\mathrm{ser}}\right)$

$\mathrm{Q}_{\mathrm{js}}=\mathrm{V}_{\mathrm{i}} \mathrm{V}_{\mathrm{j}} \mathrm{b}_{\mathrm{ser}} \cos \left(\delta_{\mathrm{ij}}+\theta_{\mathrm{ser}}\right)$

Based on Eqns. (7), (8), (10) and (11), the power injection model of the series connected voltage source can be seen as two dependant power injections at auxiliary buses i and j, as shown in Fig. (4).

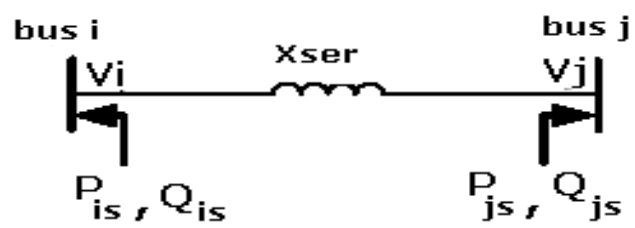

Equivalent power injection of Equivalent power injection of series branch at bus $i \quad$ series branch at bus $j$

Figure 4: Equivalent power injections of series branch.

\subsubsection{Shunt Connected Voltage Source Converter Model}

In UPFC, the shunt branch is used mainly to provide both the real power, $\mathrm{P}_{\text {ser }}$, which is injected to the system through the series branch, and the total losses within the UPFC. If the losses are to be neglected in the real power injection of the shunt connected voltage source at bus $\mathrm{i}, \mathrm{P}_{\mathrm{sh}}$ is then equal to the injected series real power $\mathrm{P}_{\text {ser }}$ through the series connected voltage source to the system. This can be expressed by: $\mathrm{P}_{\text {ser }}+\mathrm{P}_{\mathrm{sh}}=0$

The apparent power supplied by the series converter is calculated as. 
$\mathrm{S}_{\mathrm{ser}}=\mathrm{V}_{\text {ser }} \mathrm{I}_{\mathrm{ij}}{ }^{*}=\mathrm{re}^{\mathrm{j} \theta_{\text {ser }}} \mathrm{V}_{\mathrm{i}}\left(\frac{\mathrm{V}_{\mathrm{i}}{ }^{\prime}-\mathrm{V}_{\mathrm{j}}}{\mathrm{j} \mathrm{X}_{\mathrm{ser}}}\right)^{*}$

Active and reactive power supplied by the series converter can be calculated from Eqn. (13):

$S_{\text {ser }}=r e^{j \theta_{\text {ser }}} V_{i}\left(\left(r e^{j \theta_{\text {ser }}} V_{i}+V_{i}-V_{j}\right) / j X_{\text {ser }}\right)^{*}$

The final form of Eqn. (14) can be written as: $S_{\text {ser }}=P_{\text {ser }}+j Q_{\text {ser }}$, where

$\mathrm{P}_{\text {ser }}=r b_{\text {ser }} V_{i} V_{j} \sin \left(\delta_{i}-\delta_{j}+\theta_{\text {ser }}\right)-r b_{\text {ser }} V_{i}^{2} \sin \theta_{\text {ser }}$

$\mathrm{Q}_{\text {ser }}=-\mathrm{rb} \mathrm{ser}_{\mathrm{ser}} \mathrm{V}_{\mathrm{i}} \mathrm{V}_{\mathrm{j}} \cos \left(\delta_{\mathrm{i}}-\delta_{\mathrm{j}}+\theta_{\text {ser }}\right)+\mathrm{rb}_{\mathrm{ser}} \mathrm{V}_{\mathrm{i}}^{2} \cos \theta_{\text {ser }}+\mathrm{rb}_{\mathrm{ser}} \mathrm{V}_{\mathrm{i}}^{2}$

The reactive power delivered or absorbed by the shunt converter is independently controllable by the UPFC and can be modeled as a separate controllable shunt reactive source. In this case the main function of reactive power is to maintain the voltage levels at bus i within acceptable limits. Consequently, steady-state UPFC mathematical model is constructed from the series connected voltage source model with the addition of a power injection equivalent to $P_{s h}+j Q_{s h}$ to bus i, as depicted in Fig. (5). Where:

$$
\mathrm{P}_{\mathrm{sh}}=-\mathrm{P}_{\mathrm{ser}}=-\mathrm{rb} \mathrm{ber}_{\mathrm{ser}} \mathrm{V}_{\mathrm{j}} \sin \left(\delta_{\mathrm{i}}-\delta_{\mathrm{j}}+\theta_{\text {ser }}\right)+\mathrm{rb}_{\mathrm{ser}} \mathrm{V}_{\mathrm{i}}^{2} \sin \theta_{\text {ser }}
$$

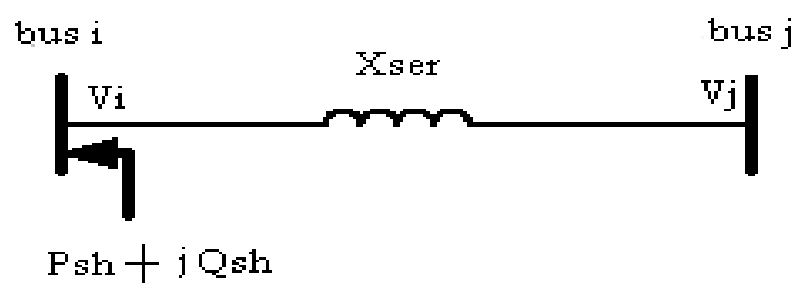

Equivalent power injection of shunt branch at bus $i$

Figure 5: Equivalent power injection of shunt branch.

\subsubsection{Whole UPFC Injection Model}

Finally, steady-state UPFC mathematical model can be constructed by combining the series and shunt power injections at both bus $i$ and bus $j$ as shown in Fig. (6). 


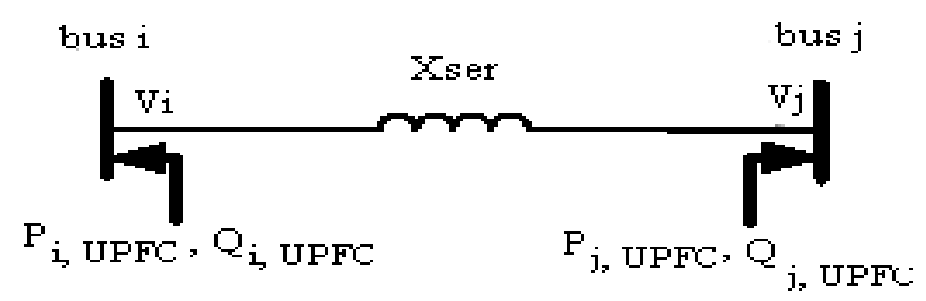

Figure 6: Steady-state UPFC mathematical model

Having $\delta_{\mathrm{ij}}=\delta_{\mathrm{i}}-\delta_{\mathrm{j}}$ The elements of the equivalent power injections in Fig. (6) are,

$\mathrm{P}_{\mathrm{i}, \mathrm{UPFC}}=\mathrm{P}_{\mathrm{is}}+\mathrm{P}_{\mathrm{sh}}=-\mathrm{rb} \mathrm{ber}_{\mathrm{ser}} \mathrm{V}_{\mathrm{i}} \mathrm{V}_{\mathrm{j}} \sin \left(\delta_{\mathrm{i}}-\delta_{\mathrm{j}}+\theta_{\text {ser }}\right)$

$\mathrm{P}_{\mathrm{j}, \mathrm{UPFC}}=\mathrm{P}_{\mathrm{js}}=\mathrm{rb} b_{\mathrm{ser}} \mathrm{V}_{\mathrm{i}} \mathrm{V}_{\mathrm{j}} \sin \left(\delta_{\mathrm{i}}-\delta_{\mathrm{j}}+\theta_{\mathrm{ser}}\right)$

$\mathrm{Q}_{\mathrm{i}, \mathrm{UPFC}}=\mathrm{Q}_{\text {is }}+\mathrm{Q}_{\mathrm{sh}}=-\mathrm{rb}_{\text {ser }} \mathrm{V}_{\mathrm{i}}^{2} \cos \theta_{\text {ser }}+\mathrm{Q}_{\mathrm{sh}}$

$\mathrm{Q}_{\mathrm{j}, \mathrm{UPFC}}=\mathrm{Q}_{\mathrm{js}}=\mathrm{rb}_{\mathrm{ser}} \mathrm{V}_{\mathrm{i}} \mathrm{V}_{\mathrm{j}} \cos \left(\delta_{\mathrm{i}}-\delta_{\mathrm{j}}+\theta_{\mathrm{ser}}\right)$

\subsection{Incorporating UPFC Injection Model in Newton-Raphson Load Flow Programs.}

Having the above derived mathematical UPFC injection model, it can be incorporated in a load flow program as follows

(a) If a UPFC is located between bus $i$ and bus $j$ in a power system, the admittance matrix is modified by adding a reactance equivalent to $X_{\text {ser }}$ between bus $i$ and bus $j$.

(b) The Jacobian matrix is afterwards modified by addition of appropriate injection powers at buses i, j according to Eqns. (18) to (21) .

(c) Considering the linearized load flow model as:

$\left[\begin{array}{l}\Delta \mathrm{P} \\ \Delta \mathrm{Q}\end{array}\right]=\left[\begin{array}{ll}\mathrm{H} & \mathrm{N} \\ \mathrm{J} & \mathrm{L}\end{array}\right]\left[\begin{array}{l}\Delta \delta \\ \Delta \mathrm{V} / \mathrm{V}\end{array}\right]$

(d) The Jacobian matrix is to be modified according to the form given in table (1). (The superscript o denotes the Jacobian elements without UPFC).

(e) Load flow study according to NR method is then performed as in normal studies. 
Table 1: Modification of Jacobian matrix

\begin{tabular}{||r|l||}
\hline $\mathrm{H}_{(\mathrm{i}, \mathrm{i})}=\mathrm{H}^{\circ}{ }_{(\mathrm{i}, \mathrm{i})}-\mathrm{Q}_{\mathrm{i}, \text { UPFC }}$ & $\mathrm{N}_{(\mathrm{i}, \mathrm{i})}=\mathrm{N}^{\circ}{ }_{(\mathrm{i}, \mathrm{i})}-\mathrm{P}_{\mathrm{j}, \text { UPFC }}$ \\
$\mathrm{H}_{(\mathrm{i}, \mathrm{j})}=\mathrm{H}^{\circ}{ }_{(\mathrm{i}, \mathrm{j})}+\mathrm{Q}_{\mathrm{j}, \text { UPFC }}$ & $\mathrm{N}_{(\mathrm{i}, \mathrm{j})}=\mathrm{N}^{\circ}{ }_{(\mathrm{i}, \mathrm{j})}-\mathrm{P}_{\mathrm{j}, \text { UPFC }}$ \\
$\mathrm{H}_{(\mathrm{j}, \mathrm{i})}=\mathrm{H}^{\circ}{ }_{(\mathrm{j}, \mathrm{i})}+\mathrm{Q}_{\mathrm{j}, \text { UPFC }}$ & $\mathrm{N}_{(\mathrm{j}, \mathrm{i})}=\mathrm{N}^{\circ}{ }_{(\mathrm{j}, \mathrm{i})}+\mathrm{P}_{\mathrm{j}, \text { UPFC }}$ \\
$\mathrm{H}_{(\mathrm{j}, \mathrm{j})}=\mathrm{H}^{\circ}{ }_{(\mathrm{j}, \mathrm{j})}-\mathrm{Q}_{\mathrm{j}, \text { UPFC }}$ & $\mathrm{N}_{(\mathrm{j}, \mathrm{j})}=\mathrm{N}^{\circ}{ }_{(\mathrm{j}, \mathrm{j})}+\mathrm{P}_{\mathrm{j}, \text { UPFC }}$ \\
\hline $\mathrm{J}_{(\mathrm{i}, \mathrm{i})}=\mathrm{J}^{\circ}{ }_{(\mathrm{i}, \mathrm{i})}$ & $\mathrm{L}_{(\mathrm{i}, \mathrm{i})}=\mathrm{L}^{\circ}{ }_{(\mathrm{i}, \mathrm{i})}+2 \mathrm{Q}_{\mathrm{i}, \text { UPFC}}$ \\
$\mathbf{J}_{(\mathrm{i}, \mathrm{j})}=\mathbf{J}^{\circ}{ }_{(\mathrm{i}, \mathrm{j})}$ & $\mathrm{L}_{(\mathrm{i}, \mathrm{j})}=\mathrm{L}^{\circ}{ }_{(\mathrm{i}, \mathrm{j})}$ \\
$\mathrm{J}_{(\mathrm{j}, \mathrm{i})}=\mathbf{J}^{\circ}{ }_{(\mathrm{j}, \mathrm{i})}-\mathrm{P}_{\mathrm{j}, \text { UPFC }}$ & $\mathrm{L}_{(\mathrm{j}, \mathrm{i})}=\mathrm{L}^{\circ}{ }_{(\mathrm{j}, \mathrm{i})}+\mathrm{Q}_{\mathrm{j}, \text { UPFC}}$ \\
$\mathbf{J}_{(\mathrm{j}, \mathrm{j})}=\mathrm{J}^{\circ}{ }_{(\mathrm{j}, \mathrm{j})}+\mathrm{P}_{\mathrm{j}, \text { UPFC }}$ & $\mathrm{L}_{(\mathrm{j}, \mathrm{j})}=\mathrm{L}^{\circ}{ }_{(\mathrm{j}, \mathrm{j})}+\mathrm{Q}_{\mathrm{j}, \text { UPFC }}$ \\
\hline
\end{tabular}

\section{STUDIED SYSTEM}

In order to investigate the feasibility of the injection power UPFC model, UPFC is applied to the six-bus Ward Hall test system shown in Fig. (7). UPFC is connected between buses 1 and 4, near bus 4 . Bus 7 is defined as a dummy bus to connect UPFC between buses 4 and 7. The UPFC control variables, i.e. (r, $\theta_{\text {ser }}$ and $Q_{\text {sh }}$ ) are the results goals in this study.

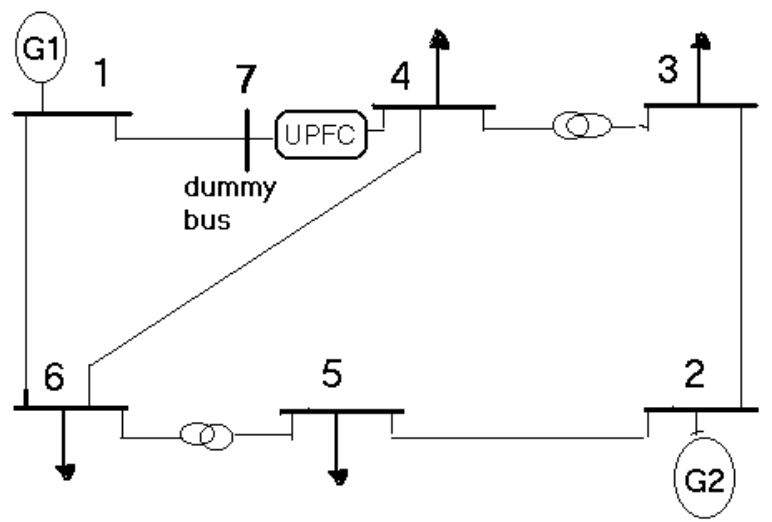

Figure 7: Six-bus Ward Hall network

\subsection{Effect of UPFC Control Variables on Power System Operation}

In this section, it is aimed to show the effect of UPFC control variables i.e.,(r, $\theta_{\text {ser }}$ and $\left.\mathrm{Q}_{\text {sh }}\right)$ on power system operation. This can be achieved by varying one of the three control variables and by keeping the other two control variables constant. First of all $\theta_{\text {ser }}$ is varied from 0 to $360^{\circ}$. Afterwards, $\mathrm{r}$ is varied from 0 to $0.1 \mathrm{p}$.u. and finally $\mathrm{Q}_{\text {sh }}$ is varied from 0 to $5 \mathrm{MVAR}$. 


\subsubsection{Effect of UPFC Control Variables on Load Nodes Voltage Magnitude}

Fig. (8) shows the variation of the voltage magnitude at load nodes with respect to $\theta_{\text {ser }}$ at different values of $r$ ( from 0 to 0.1 p.u. with interval step 0.01) and $\mathrm{Q}_{\mathrm{sh}}=0$. The figure shows the voltage magnitude at all load nodes at $(\mathrm{r}=0.1)$ when $\theta_{\text {ser }}$ is varied from 0 to $360^{\circ}$. It oscillates around its original value i.e. without UPFC connection $(\mathrm{r}=0)$. The increase of $\mathrm{r}$ causes increase in the amplitude of the voltage magnitude. All voltages reach its maximum value at $\theta_{\text {ser }}=15^{\circ}$.
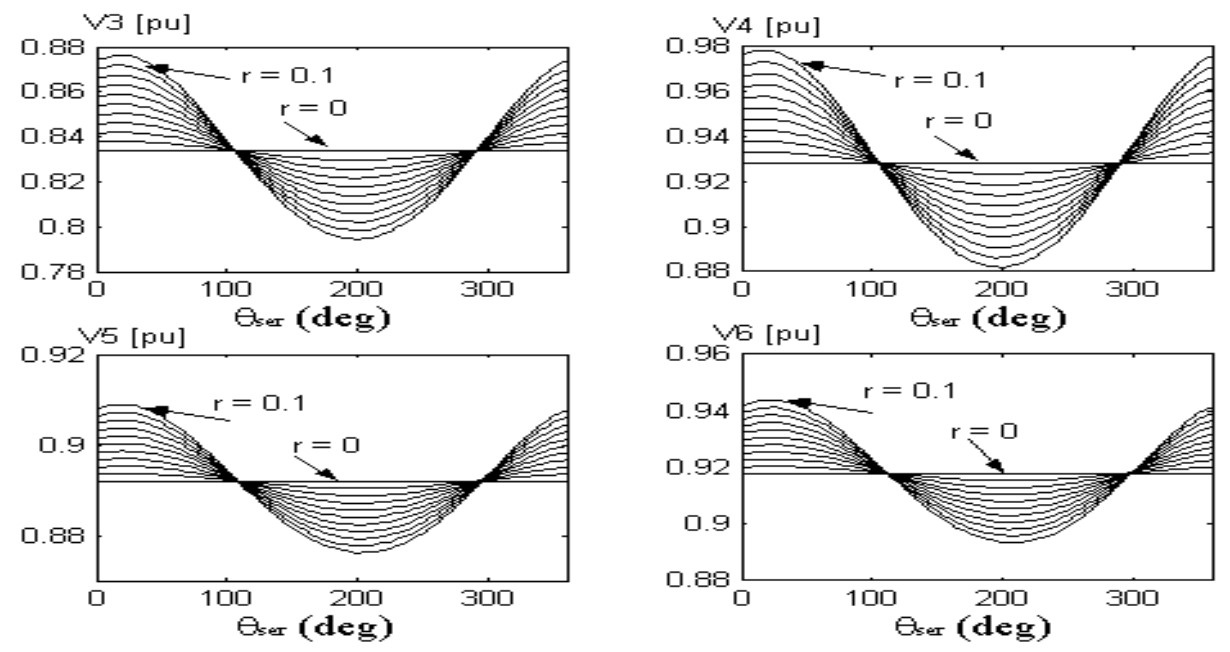

Figure 8: The variation of load nodes voltage magnitude versus $\theta_{\text {ser }}$ when $r$ varied from 0 to 0.1 and $\mathrm{Q}_{\mathrm{sh}}=0$.

Figure (9) shows the variation of the voltage magnitude at bus 4 versus $r$ at $\theta_{\text {ser }}=(0$, $90^{\circ}, 180^{\circ}$, and $270^{\circ}$ ) and $\mathrm{Q}_{\mathrm{sh}}=0$. The figure shows that the voltage magnitude has a straight line relation with $\mathrm{r}$ at certain $\theta_{\text {ser }}$ and $\mathrm{Q}_{\text {sh. }}$.

Figure (10) shows the variation of the voltage magnitude at bus 4 with both $r$ and $\theta_{\operatorname{ser}}$ at $\mathrm{Q}_{\text {sh }}=0$, When $\mathrm{r}$ is varied from 0 to $0.1 \mathrm{p}$.u. and $\theta_{\text {ser }}$ is varied from 0 to $360^{\circ}$. This figure represents the area of control for voltage magnitude at bus 4 for all operation conditions of UPFC at $\mathrm{Q}_{\text {sh }}=0$.

Figure (11) shows the variation of the load nodes voltage magnitude versus $\theta_{\text {ser }}$ at $r$ equal 0.1 p.u. and $\mathrm{Q}_{\mathrm{sh}}=(0,5) \mathrm{MVAR}$. This figure shows that the reactive power delivered from the shunt converter has no effect on the shape of change of voltage magnitude versus $\theta_{\text {ser }}$. The UPFC shunt reactive power causes raise in the voltage magnitude with certain value. 


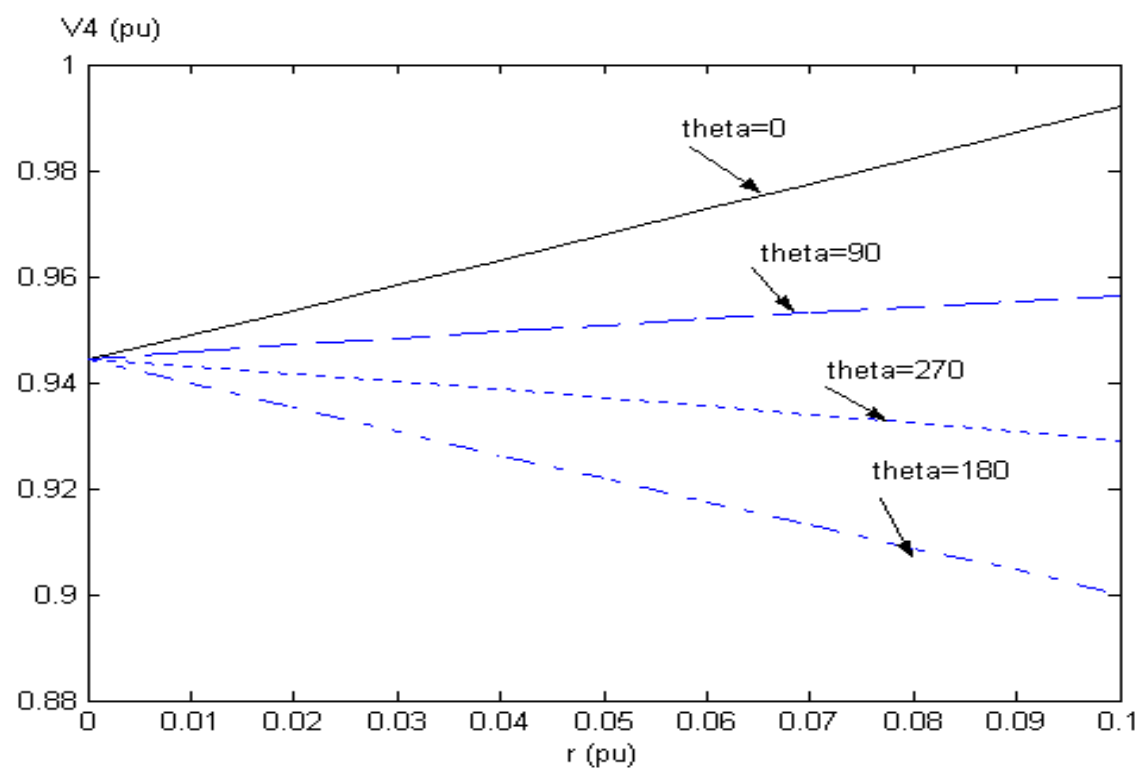

Figure 9: Variation of voltage magnitude at bus 4 versus $r$ at $\theta_{\text {ser }}=\left(0,90^{\circ}, 180^{\circ}\right.$, and $270^{\circ}$ ) and $\mathrm{Q}_{\mathrm{sh}}=0$.

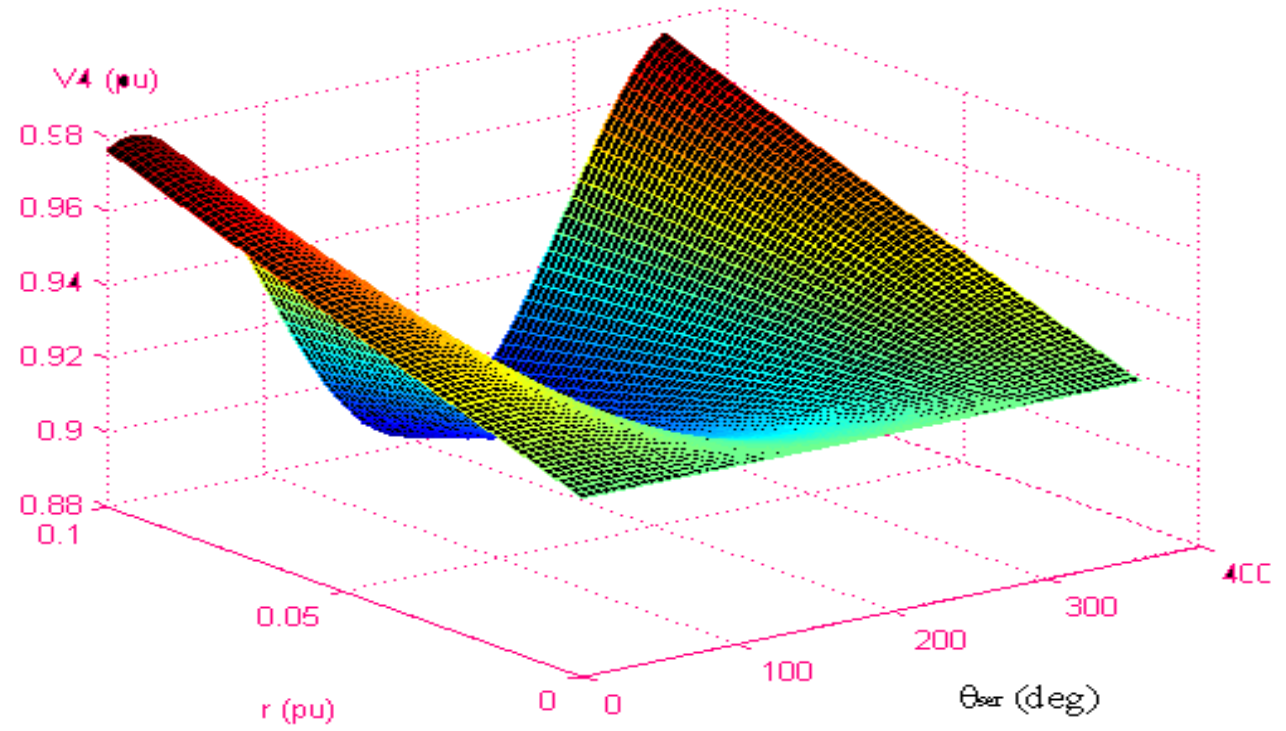

Figure 10: Control region of voltage magnitude at bus 4 at $\mathrm{Q}_{\mathrm{sh}}=0$. 

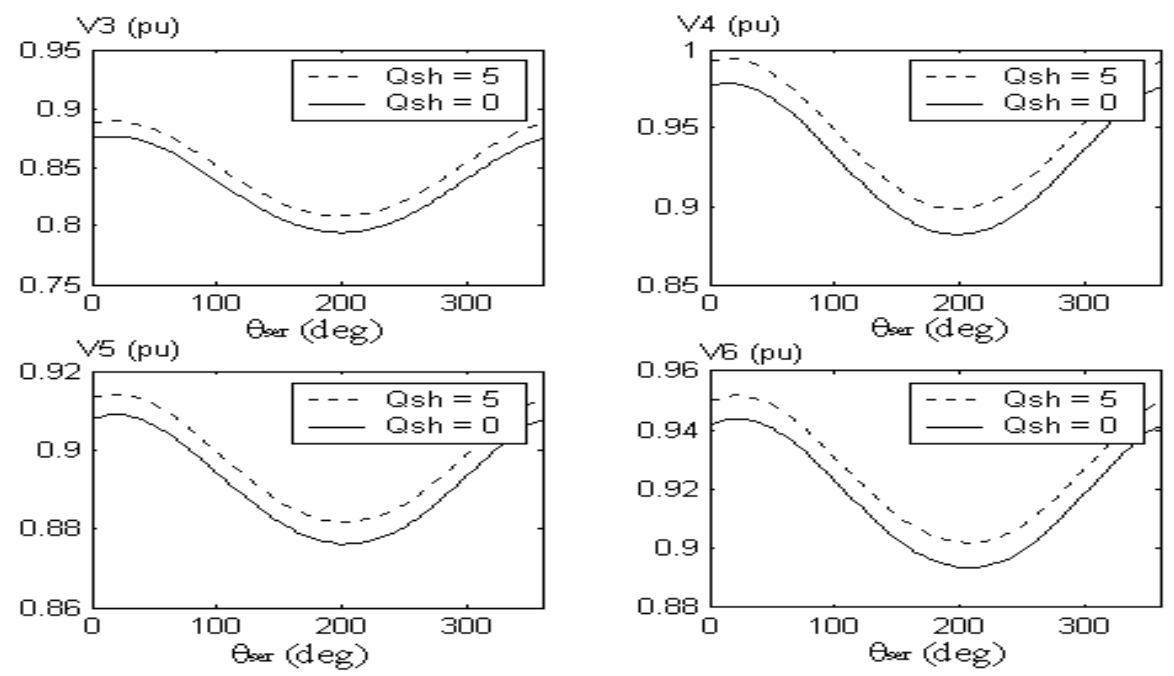

Figure 11: Variation of voltage magnitude versus $\theta_{\text {ser }}$ at $r=0.1$ and $Q_{\text {sh }}=(0,5)$ MVAR.

\subsubsection{Effect of UPFC Control Variables on Line Active and Reactive Power Flows}

Figs. 12a and $12 \mathrm{~b}$ show the change of line active and reactive power flows from bus 1 to bus 4, respectively, versus $\theta_{\text {ser }}$ at different values of $r$ and $Q_{\text {sh }}=0$ [8]. Figure $12 \mathrm{c}$ shows the Q-P characteristics of this line at the same conditions.
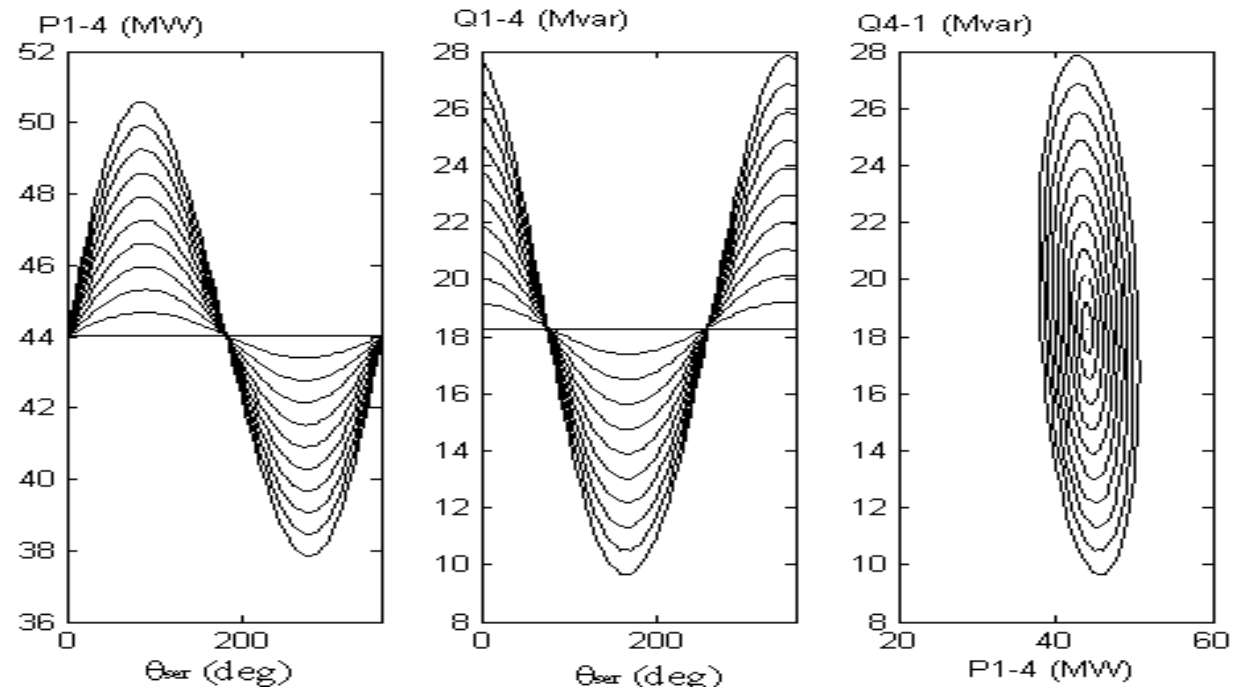

Figure 12: Line (a) Active power, (b) Reactive power, and (c) Q-P characteristics. 
Figs. 13 and 14 show the variation of the line active and reactive power versus $r$ at $\theta_{\text {ser }}=\left(0,90^{\circ}, 180^{\circ}\right.$, and $\left.270^{\circ}\right)$ and $Q_{\text {sh }}=0$, respectively. The figures show that both line active and reactive power have a straight line relation with $r$ at certain $\theta_{\text {ser }}$ and $Q_{\text {sh }}$.

Figs. 15 and 16 show the control region of UPFC for the line active and reactive power flow at $\mathrm{Q}_{\mathrm{sh}}=0$, respectively.

Figure 17 shows the variation of the line active and reactive power versus $\theta_{\text {ser }}$ at $r=0.1$ p.u. and $\mathrm{Q}_{\mathrm{sh}}=(0,5) \mathrm{MVAR}$. The Figure shows that the shunt reactive power delivered by UPFC shunt converter has no effect on the line active power and cause decrease in the line reactive power.

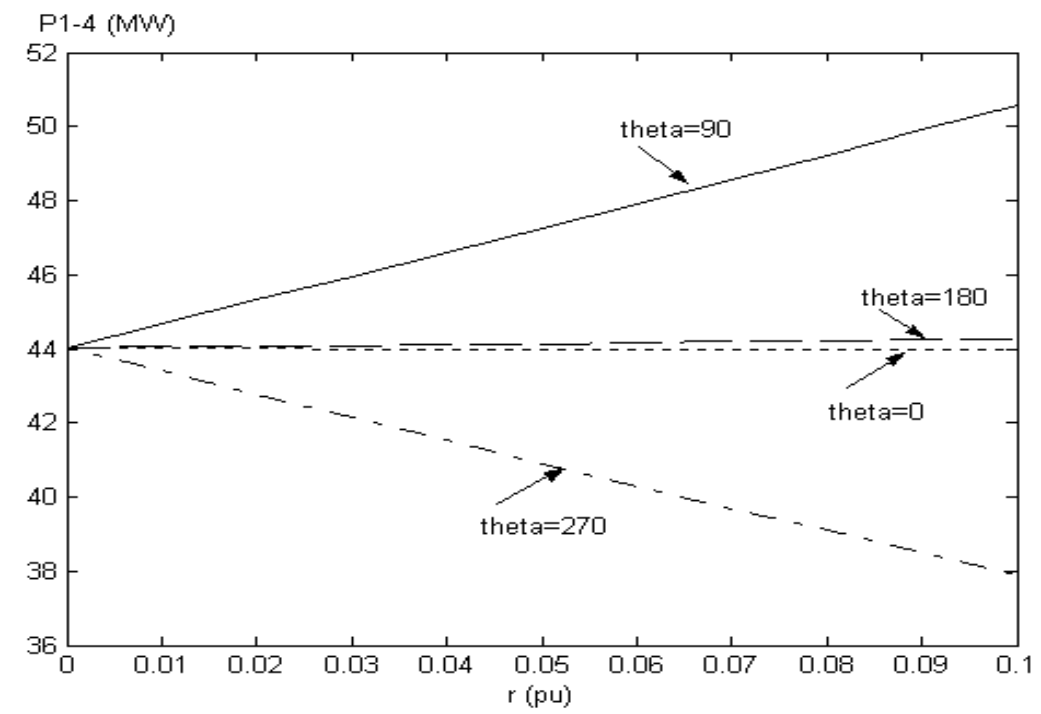

Figure 13: Variation of line active power versus $r$ at $\theta_{\text {ser }}=\left(0,90^{\circ}, 180^{\circ}\right.$, and $\left.270^{\circ}\right)$ and $\mathrm{Q}_{\mathrm{sh}}=0$.

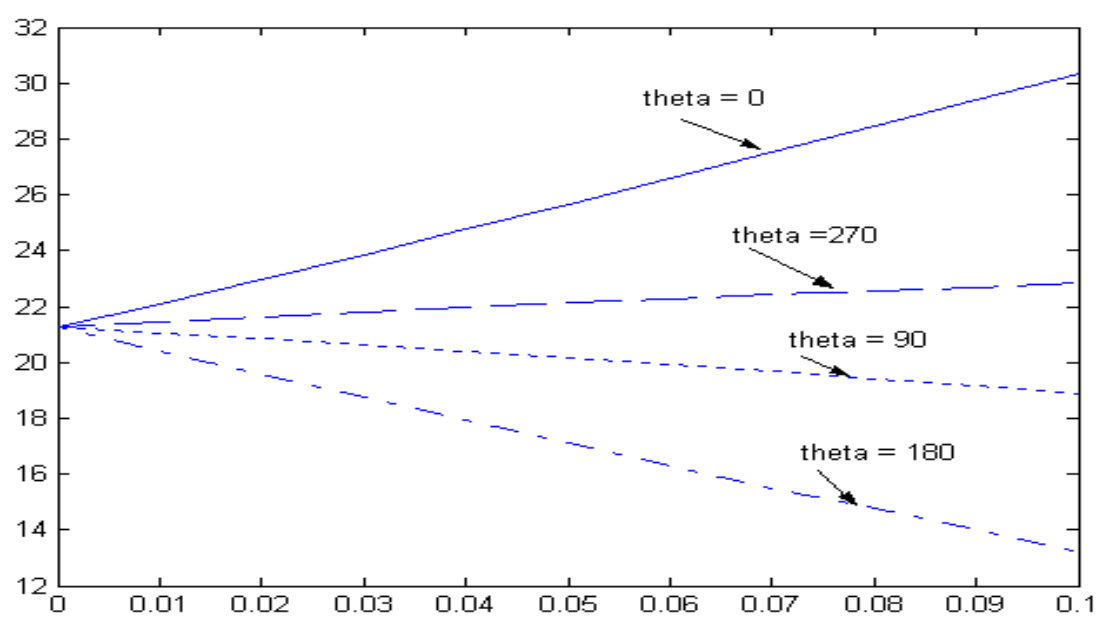

Figure 14: Variation of line reactive power versus $r$ at $\theta_{\text {ser }}=\left(0,90^{\circ}, 180^{\circ}\right.$, and $\left.270^{\circ}\right)$ and $\mathrm{Q}_{\text {sh }}=0$. 


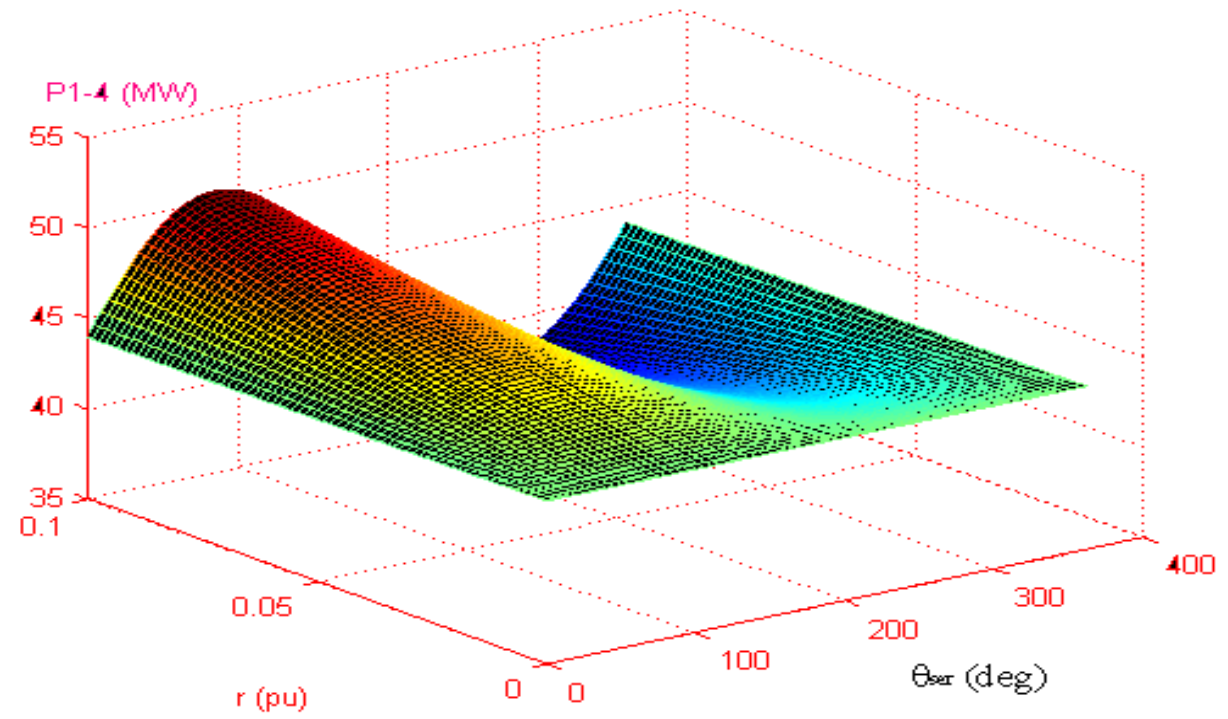

Figure 15: Control region of line active power from bus 1 to bus 4 at $\mathrm{Q}_{\mathrm{sh}}=0$.

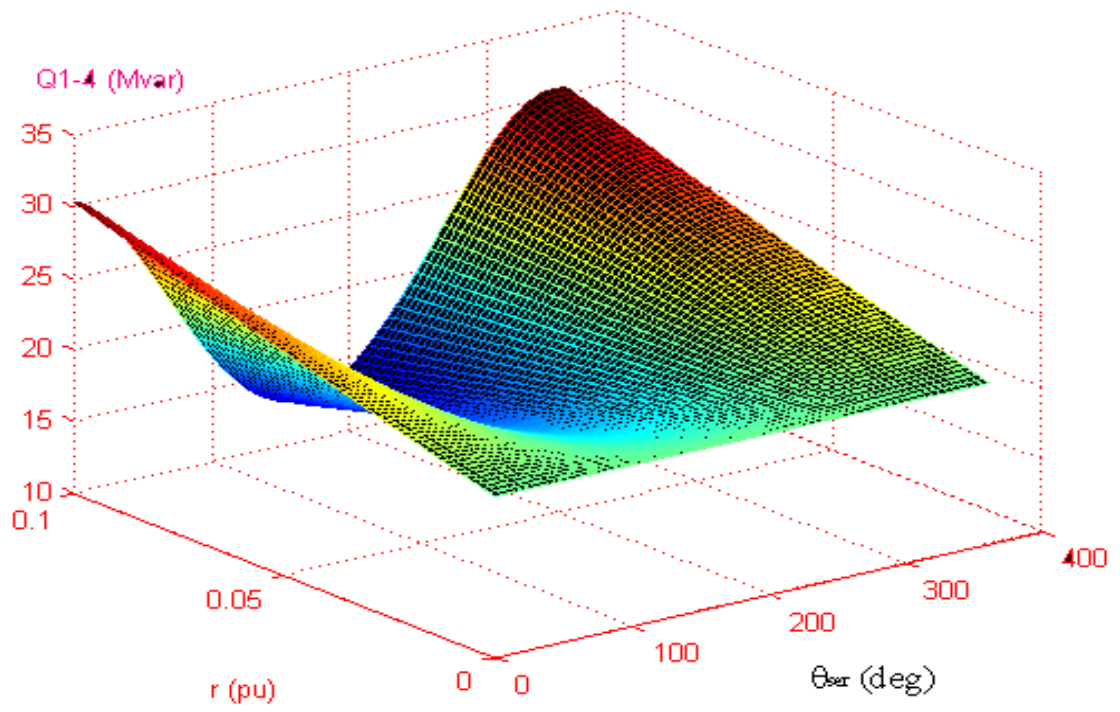

Figure 16: Control region of line reactive power from bus 1 to bus 4 at $\mathrm{Q}_{\mathrm{sh}}=0$. 

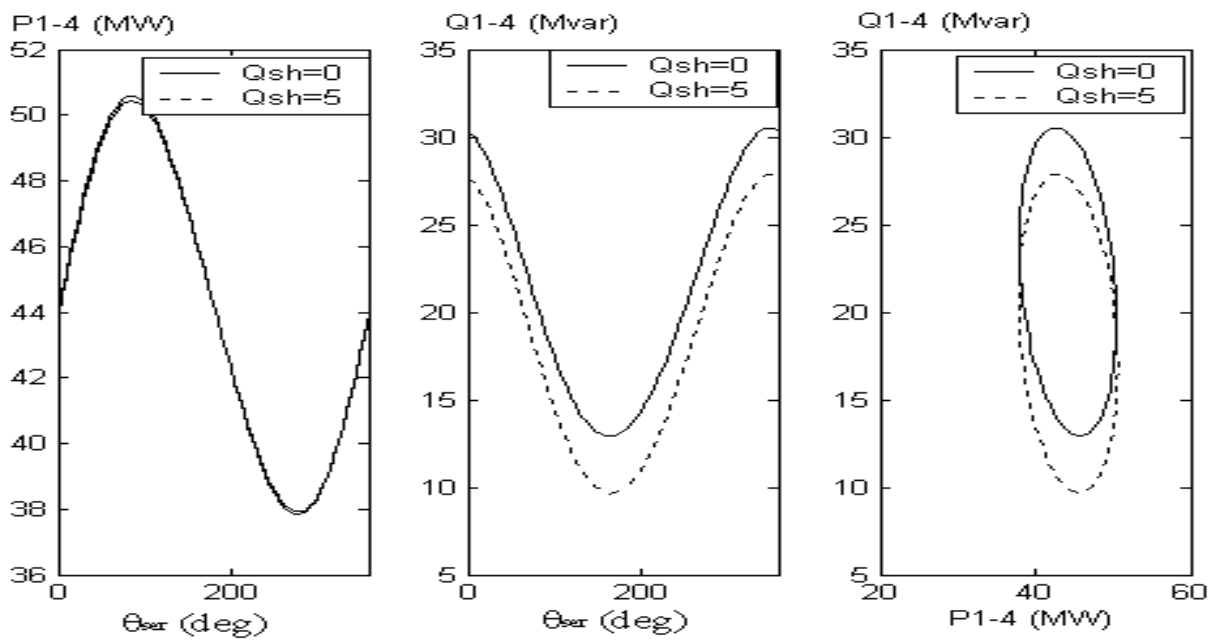

Figure 17: Line (a) Active power, (b) Reactive power, and (c) Q-P characteristics at $\mathrm{Q}_{\mathrm{sh}}=(0,5)$ MVAR.

\subsubsection{Effect of UPFC Control Variables on Generated Active and Reactive Power from Slack Bus and Reactive Power From PV Buses}

Figs. 18a and 18b show the variation of the generated active and reactive power from slack bus, respectively, versus $\theta_{\text {ser }}$ at different values of $r$ and $Q_{s h}=0$. Figure $17 \mathrm{c}$ shows the variation of the generated reactive power from bus 2 that represents the PV bus, at the same conditions.
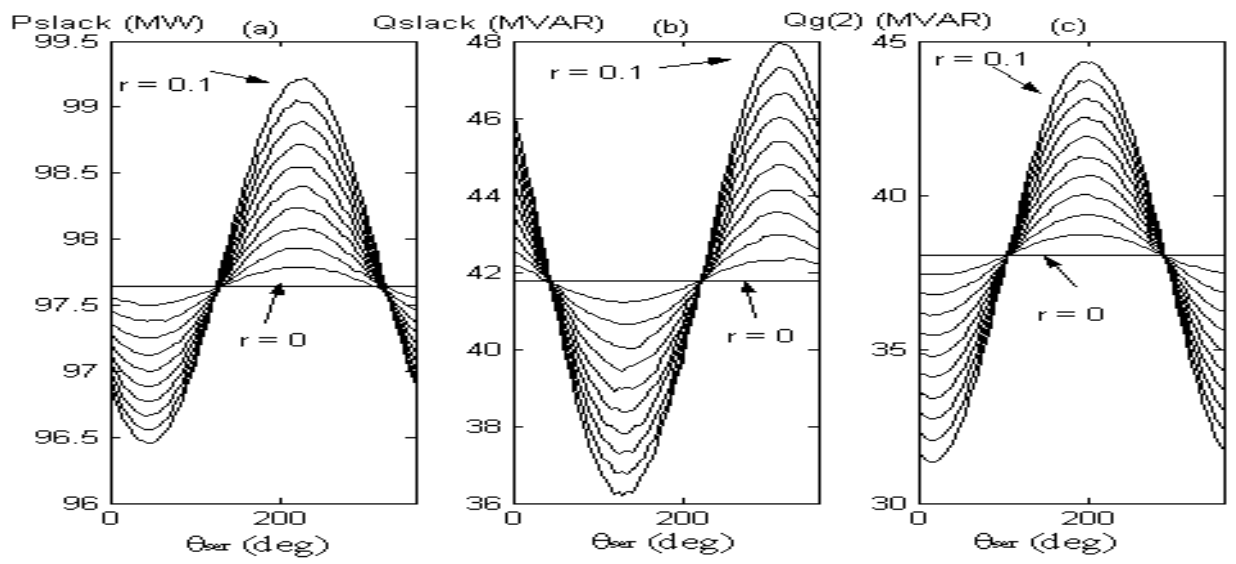

Figure 18: Variation of generated (a) Active power, (b) Reactive power form slack bus and (c) Reactive power from bus PV bus, versus $\theta_{\text {ser }}$

Figs. 19a, 19b and 19c show the variation of the generated active and reactive power form slack bus and reactive power from $P V$ bus versus $\theta_{\text {ser }}$ at $r=0.1$ p.u. and $Q_{\text {sh }}=(0$, 
5) MVAR. The figures show that the UPFC shunt converter reactive power causes decrease in both generated active and reactive power.
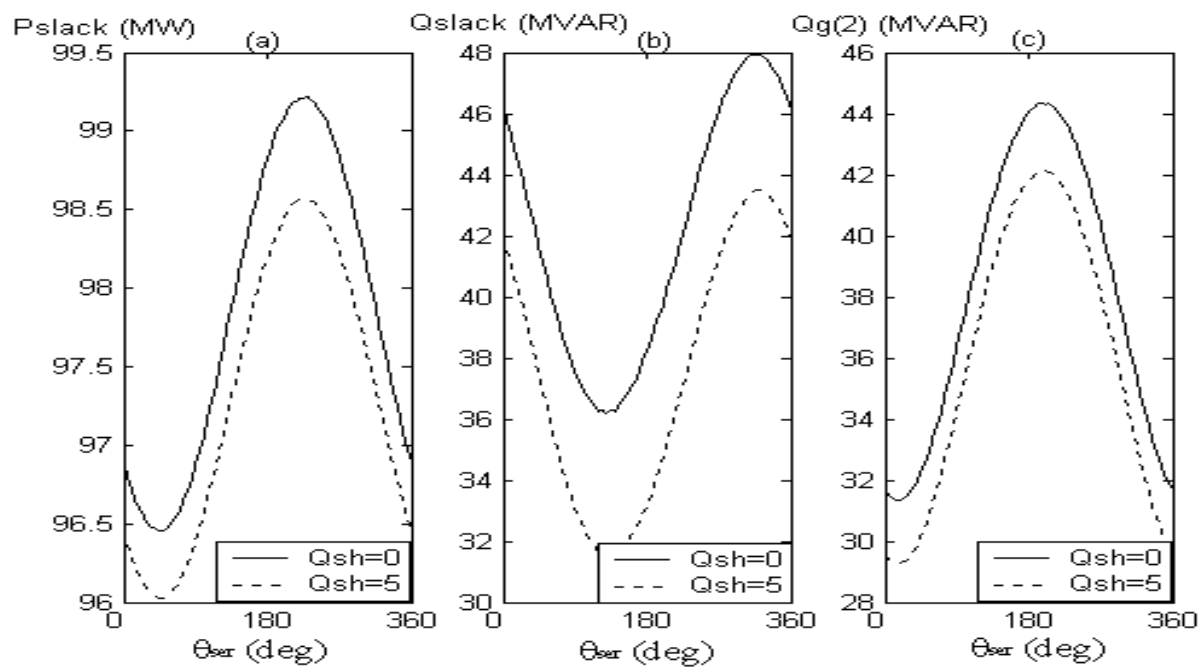

Figure 19: Variation of generated (a) Active power, (b) Reactive power from slack bus and (c) Reactive power from bus PV bus, versus $\theta_{\text {ser }}$ at $r=0.1$ and $\mathrm{Q}_{\text {sh }}=(0,5)$ MVAR.

\subsubsection{Effect of UPFC Control Variables on Total System Real and Reactive Power Loss}

Figs. 20a and 20b show the variation of the total system real and reactive power loss versus $\theta_{\text {ser }}, r=0.1$ p.u and $Q_{\text {sh }}=(0,5)$ MVAR. The figures show that the UPFC shunt converter reactive power causes decrease in both total system real and reactive power loss.
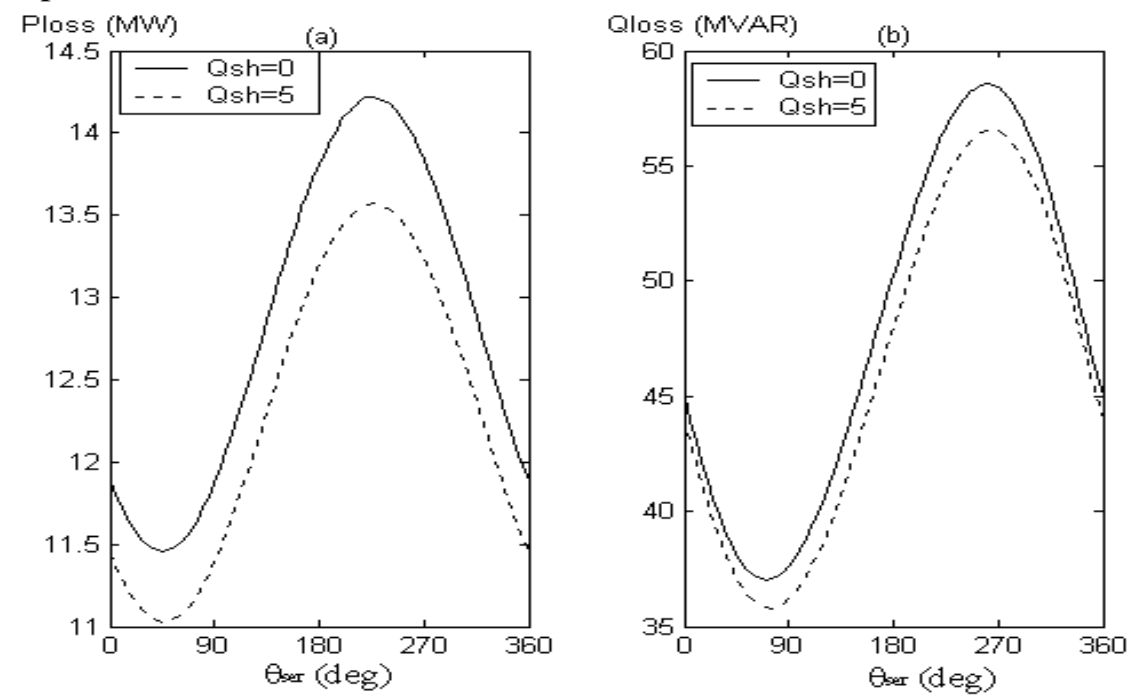

Figure 20: Total system (a) Real, (b) Reactive power loss at $Q_{s h}=(0,5)$ MVAR. 


\subsection{Effect of UPFC Location in the Same Line, on Power Flow and Total Real Power Loss}

A comparative study regarding the effects of UPFC location on important power parameters is carried out for two different UPFC locations. First position named as " position A" refers to UPFC location near bus 4 in line 1-4, while second position named as "position B" refers to UPFC location at the middle of line 1-4. comparable simulation results are graphically represented in Figure21.There were no significant changes in either line real power flow, reactive power flow or total system real power loss.
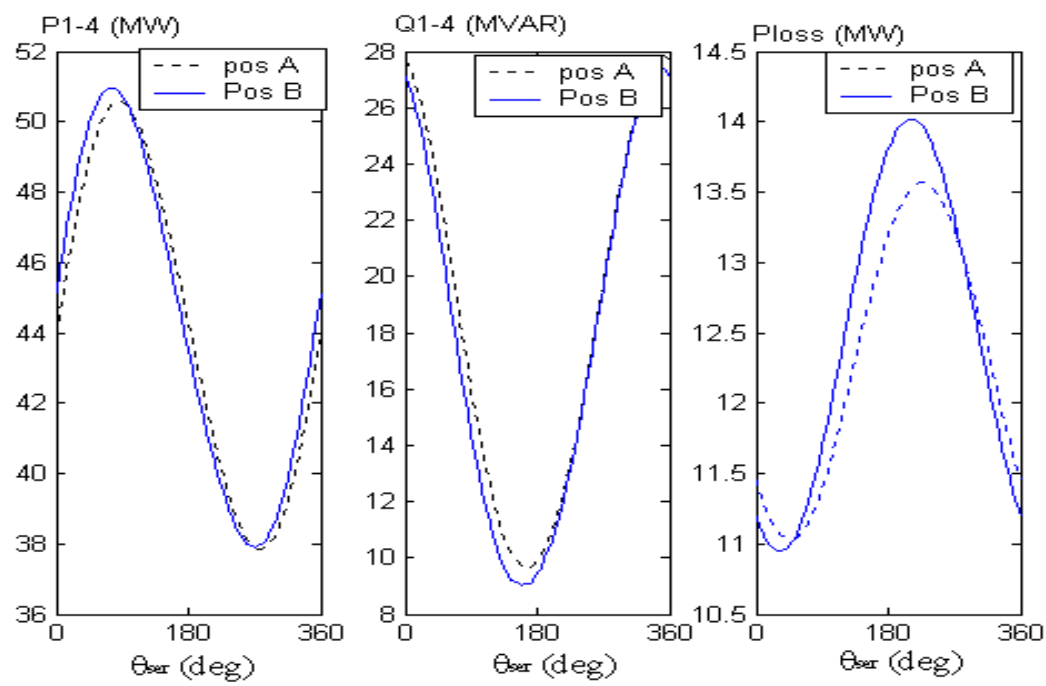

Figure 21: Effect of UPFC location on (a) Active power flow, (b) Reactive power flow, and (c) Total system real power loss.

\subsection{Power Flow Characteristics of UPFC}

From Eqns. (15) and (16), it is possible to determine the active and reactive power supplied from the series converter. As considered that UPFC is lossless, so the shunt converter active power equal in magnitude to the series converter active power but with opposite sign. The reactive power delivered from shunt converter is not considered here, but its effect can be modeled as a separate controllable shunt reactive source. Figs. 22(a), 22(b) and 22(c) show the variation of the series converter active power, series converter reactive power and shunt converter active power with series control angle respectively. Figure 22(d) shows the Q-P characteristics of the series converter. 

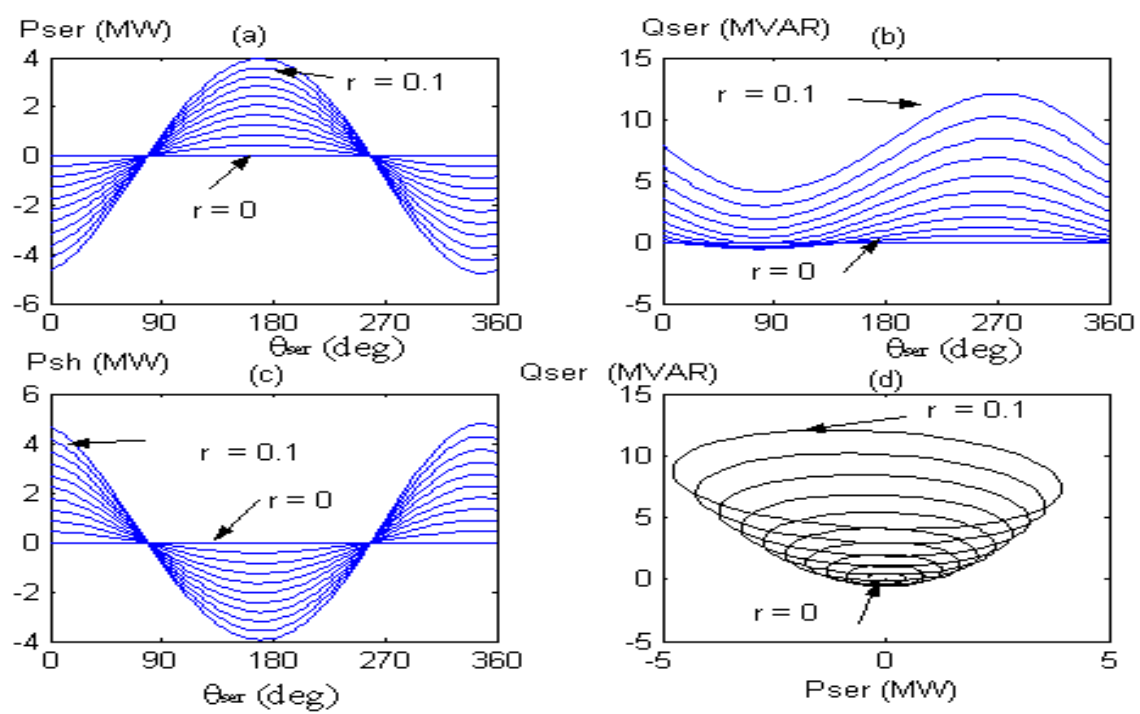

Figure 22: Variation of (a) Series converter active power, (b) Series converter reactive power, and (c) shunt converter active power, with $\theta_{\text {ser }}(\mathrm{d})$ Q-P characteristics of series converter.

\section{CONCLUSIONS}

The following conclusions can be pointed;

1) In this paper a UPFC injection power flow model has been incorporated in a MATLAB power flow program based on NR technique.

2) The UPFC power flow model is based on the representation of UPFC by two voltage sources in series with reactances.

3) Using this UPFC power flow model, the effect of UPFC control variables on power system operation has been investigated, the effect of UPFC location on the power flow and total system real power loss has been illustrated and the UPFC power flow characteristics has been cleared. All results indicate that good convergence and high accuracy are achieved by this UPFC power flow model.

4) The simulation examples have shown that UPFC is a powerful FACTS device in controlling the voltage magnitude, the flow of real power, as well as the flow of reactive power.

5) The studied on the test system also show that the introduction of UPFC can disturb the system voltage profile at the neighboring buses significantly unless a voltage regulation support at those buses is not provided.

6) The incorporation of UPFC has also changed the generated active and reactive power from slack bus, generated reactive power from PV buses and overall transmission losses of the studied system. 
7) The comparative study regarding the effects of UPFC location have shown that there were no significant changes in either line power flow or overall transmission real losses when the UPFC position is changed on the line.

\section{REFERENCES}

[1] A. Edris, "FACTS Technology Development: An Update “, IEEE Power Engineering Review, Vol.20, pp. 4-9, March 2000.

[2] M.Z Elsadek “Power Systems Power Quality”, Book, Mukhtar press, Assiut, 2004.

[3] A. Edris, A.S. Mehraban, M. Rahman, L. Gyugyi, S. Arabi, and T. Reitman, "Controlling The Flow Of Real and Reactive Power", IEEE Computer Application In Power, Vol. 11, pp. 20-25, January 1998.

[4] R.J. Nelson, J. Bian, and S.L. Williams, "Transmission Series Power Flow Control", IEEE Trans. On Power Delivery, pp.504-510, 1995.

[5] Naihu Li, Yan Xu, and Heng Chen, "FACTS-Based Power Flow Control in Interconnected Power Systems", IEEE Trans. On Power Systems, Vol. 15, pp.257262, 2000.

[6] M. Noroozian, L. Angquist, M. Ghandhari, and G. Anderson, "Use Of UPFC for Optimal Power Flow Control”, IEEE Trans. On Power Delivery, Vol. 12, No. 4, , pp. 1629-1634, October 1997.

[7] Hadi Saadat, "Power System Analysis", Book, International Edition, 1999.

[8] Alireza Farhangfar, S. Javad Sajjadi, and Saeed Afsharnia, "Power Flow Control and Loss Minimization with Unified Power Flow Controller (UPFC)" Electrical and Computer Engineering, 2004, Canadian Conference, Vol.1, pp.385-388, May, 2004.

[9] M. Tumay and A. M. Vural, "Analysis and Modeling Of Unified Power Flow Controller: Modification Of Newton-Raphson Algorithm and User-Defined Modeling Approach For Power Flow Studies", The Arabian Journal For Science and Engineering, Vol. 29, No. 2B, pp. 135-153, October 2004.

\section{إدماج نموذج حقن القرة لمنظم مسارات القدرة الموحدة في برامج مسارات القدرة}

يهـدف هــذا البحــث إلـى إدمــاج نمـوذج الحالــة المسـتقرة لمـنظم مســارات القـدرة الموحدة(UPFC) في برامج مسارات القدرة باستخدام نموذج حقن القدرة • يعتمد نموذج حقن القدرة الذي تم اختياره علي تمثيل منظم مسارات القدرة الموحد في حالة الاستقرار بمصدرين للجهد مع معا وقه علي التوالي لكل منهما. وباستخدام هذا النموذج يتم توضيح 
تأثثر متغيرات التحكم في منظم مسارات القدرة الموحدة علي جهد النظام والقدرة الفعالة وغير الفعالة التي تسرى في خطوط النقل و الفقد الكلى للقدرة في النظام و القدرة المتولدة. وباستخدام هذا النموذج يتم أيضا دراسة تأثير المكان الذي يوضع به منظم مسارات القدرة الموحدةعلي مسارات القدرة و الفقد الكلى للقدرة في النظام. و لقد وجد أنه باستخدام هذا النموذج يتم ظهور خصائص مسار القدرة داخل منظم مسارات القدرة الموحدة. 